\title{
Contrasting the Pathogen Loads in Co-Existing Populations of Phytophthora pluvialis and Nothophaeocryptopus gaeumannii in Douglas Fir Plantations in New Zealand and the Pacific Northwest United States
}

\author{
Mireia Gómez-Gallego, ${ }^{1,2, \dagger}$ Jared M. LeBoldus, ${ }^{3}$ Martin Karl-Friedrich Bader, ${ }^{1}$ Everett Hansen, ${ }^{3}$ \\ Lloyd Donaldson, ${ }^{2}$ and Nari Michelle Williams ${ }^{2}$ \\ ${ }^{1}$ School of Science, Auckland University of Technology, Auckland 1010, New Zealand \\ ${ }^{2}$ New Zealand Forest Research Institute (Scion), Rotorua 3046, New Zealand \\ ${ }^{3}$ Department of Botany and Plant Pathology, Oregon State University, Corvallis, OR 97331, U.S.A. \\ Accepted for publication 3 July 2019.
}

\begin{abstract}
The emergence of Phytophthora pluvialis as a foliar pathogen of Douglas fir in New Zealand and the Pacific Northwest United States has raised questions about its interaction with the widespread Swiss needle cast (SNC) disease. During Spring 2017, we repeatedly sampled 30 trees along an environmental gradient in each region and 292 additional trees in a longitudinal transect to assess the $P$. pluvialis epidemic and the association between P. pluvialis and Nothophaeocryptopus gaeumannii, which are causal agents of SNC. Both pathogens were consistently more abundant in the host's exotic environment in New Zealand. In both areas,
\end{abstract}

ABSTRACT the two pathogens co-exist in different spatial scales for regions and needles. The relative abundance of both pathogens was negatively correlated in the Pacific Northwest, where both presumably have co-existed for longer. Our findings confirmed the interaction of P. pluvialis and N. gaeumannii as foliar pathogens of Douglas fir and suggest a within-site spatial variation in the Pacific Northwest.

Keywords: ascomycete, competition, multiple infection, oomycete, red needle cast
Oomycetes in the genus Phytophthora are an aggressive group of pathogens in agricultural and forest ecosystems. In forests, they were traditionally recognized as belowground pathogens that are soilborne and cause root rot in trees (Brasier et al. 1993; Day 1938; Newhook and Podger 1972; Vettraino et al. 2005). However, increasing disease reports have revealed greater diversity in the biology and life history within the genus Phytophthora. In forest ecosystems, infections caused by soilborne and airborne Phytophthora species have been described from the roots to the leaves (Brasier et al. 2005; Hansen 2015; Hansen et al. 2003; Kozanitas et al. 2017). During the past decade, Phytophthora diseases associated with the foliage of conifers have emerged and are a growing concern for economically important plantation species (Brasier and Webber 2010; Dick et al. 2014; Durán et al. 2008).

Phytophthora pluvialis Reeser, Sutton, and Hansen belongs to this group of foliar Phytophthora pathogens and is the causal agent of red needle cast (RNC) disease in radiata pine (Pinus radiata [D. Don]) (Dick et al. 2014). Recently, it has been reported to cause early defoliation and shoot dieback on Douglas fir (Pseudotsuga menziesii [Mirb.] Franco) in Oregon (United States) and New Zealand (Hansen et al. 2015). P. pluvialis typically infects the lower

†Corresponding author: M. Gómez-Gallego; mireia.gomez@slu.se

Current address of first author: Department of Forest Mycology and Plant Pathology, Swedish University of Agricultural Sciences (SLU), P.O. 7026, SE-750 07, Uppsala, Sweden

Funding: The authors thank The Forest Owners Association of New Zealand and Ministry of Business Innovation and Employment of New Zealand (grant C04X1305), who provided the funding for this work.

*The $\boldsymbol{e}$-Xtra logo stands for "electronic extra" and indicates that two supplementary figures and one supplementary table are published online.

The author(s) declare no conflict of interest.

This article is in the public domain and not copyrightable. It may be freely reprinted with customary crediting of the source. The American Phytopathological Society, 2019. canopy of both radiata pine and Douglas fir trees. Infection can progress upward to the top of the live crown under prolonged periods of weather conducive for pathogen development. In New Zealand, epidemic episodes of polycyclic infections start in autumn, with peaks in late winter and early spring. Although symptomatic needles in radiata pine turn red prior to being cast, in Douglas fir, needles usually fall from trees before symptoms are clearly visible.

The casting observed from Douglas fir has raised the question of whether P. pluvialis has a role in defoliation events previously associated with Swiss needle cast (SNC) disease caused by the ascomycete Nothophaeocryptopus gaeumannii (T. Rohde) Videira, C. Nakash., U. Braun \& Crous. In its native range, which is the Pacific Northwest in the United States, this fungus was considered unimportant (Boyce 1940) until the first significant outbreaks occurred in the late 1980s and 1990s (Hansen et al. 2000). The disease has since spread from 53,050 ha in 1996 to 238,705 ha in 2015 in the Oregon Coast Range (Ritóková et al. 2016). In New Zealand, it was first detected in 1959 on the North Island, and it gradually progressed to the southern tip of the South Island by the late 1980s (Hood and Kershaw 1975; Hood et al. 1990).

Recently, the potential for co-infection of Douglas fir needles by $P$. pluvialis and N. gaeumannii has been demonstrated in a detached needle assay (Gómez-Gallego et al. 2017). The primary mechanism of pathogenicity of $N$. gaeumannii is through pseudothecia developing within stomata, thus impeding their function and leading to impaired photosynthesis (Manter et al. 2000). The resulting negative needle carbon budgets cause defoliation and growth reduction (Manter et al. 2003). P. pluvialis sporangia can either germinate directly or release zoospores that would reach needle surfaces by water splash. Following release, the zoospores would encyst and colonize the intercellular space. Sporangia clusters emerge from stomatal openings, and the cycle starts again. Stomata are an important component of the infection biology and disease etiology of both pathogens, but the seasonality and epidemiology of both diseases seem to be different. P. pluvialis is polycyclic but $N$. gaeumannii has a monocyclic nature, with one infection cycle per year that occurs during the late spring following ascospore release (Hood et al. 1990). 
The establishment of new pathogens in an ecosystem is a result of their obligatory interaction with susceptible hosts in a conducive environment. Although less explored, the interactions of a pathogen with other microorganisms are extremely important in shaping the development of disease outbreaks (Dickie et al. 2017). In general, co-infection is considered to result in increased within-host growth rates and higher transmission potential (Alizon et al. 2009; Laine 2011; Nowak and May 1994; van Baalen and Sabelis 1995). However, pathogens cannot co-exist in the same host in the long-term when they are in competition for the same resources (Alizon and van Baalen 2008). This competition will lead to an evolutionary equilibrium, and the outcome will depend on several factors such as priority effects, availability of nutrients, climate, and genotype (Abdullah et al. 2017; AlNaimi et al. 2005; Kozanitas et al. 2017; Laine 2011; Simpson et al. 2004).

Tree leaves are nutritionally defined niches where pathogens with similar requirements naturally compete. There are several hypothesized outcomes of these interactions. For example, following an initial increase in growth, depletion of resources can lead to growth reduction over time, impacting both microorganisms (Jonkers et al. 2012; Rankin et al. 2007). Conversely, competition for resources could result in the selection of species that present the most efficient resource exploitation strategies, thereby outgrowing its competitors (Abdullah et al. 2017). N. gaeumannii creates appressoria to access intracellular space and extract nutrients (Stone et al. 2008a). Although this infection structure is common in Phytophthora species (Fawke et al. 2015; Hayden et al. 2013), they have not been observed in needles inoculated with $P$. pluvialis to date.

Other pathogen-pathogen interactions that would lead to the selection of one species over another are competitive exclusion via chemical or mechanical interference and indirect (or apparent) competition through targeted defense responses (Abdullah et al. 2017; Mideo 2009). Neutral interactions, whereby both pathogens can co-exist, can also occur when pathogens undergo niche specialization either in space or in time (Abdullah et al. 2017; Al-Naimi et al. 2005; Desprez-Loustau et al. 2018; Fitt et al. 2006). P. pluvialis was first detected in 2002 in baited streams, soil, and canopy drip in a mixed tanoak-Douglas fir forest in southwest Oregon (Reeser et al. 2013). It has been suggested that $P$. pluvialis is endemic to Oregon (Brar et al. 2018; Reeser et al. 2013). Regardless of its center of origin, it is clear that $P$. pluvialis has been present in the Pacific Northwest for longer than it has been in New Zealand (Brar et al. 2018). Therefore, the Pacific Northwest and New Zealand offer an opportunity to investigate differences in epidemiology and to begin to characterize the interaction between $P$. pluvialis and $N$. gaeumannii.

In the present study, we aimed to explore the extent of $P$. pluvialis epidemics in both the Pacific Northwest and New Zealand through a one-time regional sampling in an extended area in each country to quantify the presence and abundance of $P$. pluvialis. Furthermore, we intended to compare the relative abundance of the two pathogens to investigate the interaction of $P$. pluvialis and $N$. gaeumannii in two environments: the Pacific Northwest (native for N. gaeumannii and Douglas fir) and New Zealand (exotic for N. gaeumannii and Douglas fir), where P. pluvialis has been more recently introduced. We hypothesized that in the Pacific Northwest, the levels of $P$. pluvialis and N. gaeumannii would be lower than those in the New Zealand population because of a longer period of co-existence and previous increased growth rates. We also speculated that the New Zealand environment would support greater pathogen abundance because of the non-native nature of both pathogens and their host in this country and because of the monospecific plantation setting. Finally, we aimed to determine the climatic drivers shaping the abundance of the two pathogens by analyzing the correlation between different climatic variables and the abundance of each pathogen.

\section{MATERIALS AND METHODS}

Study sites and field sampling. The study area included two different regions (hereafter referred to as countries), New Zealand and the Pacific Northwest. Both countries have a temperate climate of the oceanic subtype, with 4 to 7 months with monthly mean air temperatures $>10^{\circ} \mathrm{C}$ and with the coldest month having a mean air temperature $>0^{\circ} \mathrm{C}$ (Belda et al. 2014). Two studies were performed in both countries: a study of the $P$. pluvialis $\times N$. gaeumannii interaction across an environmental gradient with sampling every 2 weeks and extensive regional sampling to compare detection rates of both pathogens at a regional level.

Sampling every 2 weeks. We selected six sites in an area of each country where $P$. pluvialis had been detected to most frequently infect Douglas fir and initiated sampling every 2 weeks. In New Zealand, the sites were located in the central plateau of the North Island. In the Pacific Northwest (referred to as Oregon for the sampling every 2 weeks), the six sites were situated in the state of Oregon and followed a longitudinal gradient from the central Oregon coast to the Cascade Mountain range (Supplementary Fig. S1A, Supplementary Table S1). Because of our limited knowledge of the variability and distribution of $P$. pluvialis infection in Douglas fir to date, we selected the study sites to cover a wide range of SNC severities to determine its potential effect on $P$. pluvialis variability. In Oregon, the variation in SNC severity in the Coast range has been described to decrease with distance from the ocean (Manter et al. 2003). In both countries, sites followed an environmental gradient of winter temperature and precipitation, which have been shown to explain SNC variability in both countries (Manter et al. 2005; Stone et al. 2007, 2008b; Watt et al. 2010). Within this environmental gradient, sites were selected from monoculture Douglas fir plantations ranging in age from 11 to 14 years. Five trees at least $5 \mathrm{~m}$ apart were selected along the edge of each plantation, where $P$. pluvialis infection is more notable. Accessible branches were shaken by hand, and the cast needles were collected on a tarp spread under the tree, placed in a labeled bag, transferred to the laboratory at $4{ }^{\circ} \mathrm{C}$, and processed within $24 \mathrm{~h}$. The needles from each tree were processed separately. One site in the North Island of New Zealand was excluded from $P$. pluvialis analyses because of the exceptional presence of geothermal activity and the complete absence of RNC at the site and surrounding area.

To monitor the pathogen infection dynamics along the environmental gradient, the same trees were sampled every 2 weeks. The sampling period corresponded to the meteorological spring in both countries. In the Pacific Northwest, the sampling began on 2 March and ended on 2 June 2017. In New Zealand, the sampling began 23 August and ended 21 November 2017. To capture the microclimate at each site, hourly values of temperature, $\mathrm{RH}$, and dew point temperature were recorded during the sampling period using a HOBO data logger with external temperature and RH sensors (MX2300 Ext Temp/RH; Onset Computer Corporation, MA, USA). HOBO data loggers were placed on an accessible branch of the middle tree at each site.

To examine the interaction of pathogens growing on the needle surfaces, subsamples of harvested needles from the New Zealand sampling every 2 weeks were prepared for microscopic observation. Needles were selected from two sites in the North Island of New Zealand for the first sampling date on the 31 August 2017 (sites Z1 and Z2). Needle segments were fixed in $4 \%$ glutaraldehyde for $1 \mathrm{~h}$ at room temperature, washed in water, dehydrated in an ethanol series, and air-dried. Dried segments were mounted on aluminum stubs with conductive carbon tape and coated with chromium before examination with a field emission scanning electron microscope (JEOL 6700; Tokyo, Japan).

Regional sampling. To estimate the distribution of pathogens in both countries, a one-time sampling survey was conducted along latitudinal transects (Supplementary Fig. S2). The survey was performed at the same time of the year in each country, immediately before the Douglas fir bud flush. In the Pacific Northwest, 39 sites (134 trees, 3 to 6 trees/site) were sampled along the coastal fog belt from southern Washington state to northern California and to the central Oregon Cascades range. In New Zealand, a total of 36 sites 
(158 trees, 2 to 5 trees/site) were sampled on both islands. Trees from the edge of adult Douglas fir plantations were sampled. The latitudinal sampling in the Pacific Northwest followed the fog belt from southern Washington state to northern California and sampling sites in the Cascade Mountain range. Sites where the pathogen had been previously detected in soil and stream samples were included in this transect. In New Zealand, the main areas with Douglas fir plantations were sampled in the North and South Islands.

Climate data. Climate data from weather stations were collected to calculate climate parameters of the previous year that could explain infection by both pathogens or either pathogen and to extrapolate data to explain gaps present in the onsite weather data time series. Climate data were obtained for all sites used for regional sampling and sampling every 2 weeks.

For the Pacific Northwest, climate data were interpolated from gridMet $4 \times 4 \mathrm{~km}$ (http://www.climatologylab.org/gridmet.html). Climate variables were daily minima and maxima for both air temperature and $\mathrm{RH}$ and precipitation. Mean daily $\mathrm{RH}$ and temperature were approximated by averaging the minimum and maximum values. For New Zealand sites, the same climatic variables were obtained from the National Institute of Water and Atmospheric Research (NIWA; New Zealand). However, only a single daily value of RH measured at 9 a.m. was available. This value was considered the mean RH for the New Zealand data set.

All primary climate data series, both from weather stations and onsite weather data loggers, were detrended by applying the Gaussian smoothing function (smth.gaussian, package smoother in R; Hamilton 2015) with a window width of 3 days. Other climate parameters were derived to test a range of biologically meaningful variables that could explain infection by either pathogen. Binary variables were calculated, with 1 corresponding to the previousday temperature $>5,6,7,8,9$, or $10^{\circ} \mathrm{C}$, and 0 corresponding to previous-day temperature lower than those temperature values. In another set of variables, 1 corresponded to previous-day $\mathrm{RH}>90$, 95,97 , or $98 \%$; similarly, for a combination of those temperature and RH levels, 1 corresponded to previous-day temperature $>5^{\circ} \mathrm{C}$ and $\mathrm{RH}>90 \%$. The number of days before sampling dates with combinations of the aforementioned conditions was also calculated for temperatures $>5,7,8,9,10$, and $12^{\circ} \mathrm{C}$ and $\mathrm{RH}>90,95$, 96, and $97 \%$.

Dew point temperature was approximated by the following formula:

$$
T_{\text {dew }}=T-\frac{100-R H}{5}
$$

where $\mathrm{T}$ is the average daily temperature and $\mathrm{RH}$ is the average daily relative humidity.

Growing degree days (GDD) were calculated using the GDD function from package chillR in R (Luedeling 2019). Different base temperature values $\left(4,5,7,8,9\right.$, and $\left.10^{\circ} \mathrm{C}\right)$ were used.

The average winter, spring, and summer temperatures and $\mathrm{RH}$ were calculated from the weather station data, as were the seasonal and annual rainfall. In the Pacific Northwest, the following months were considered for each season: winter, December to February; spring, March to May and April to June (two different periods were considered); and summer, June to August. In New Zealand, the period from June to August was considered winter, September to November and October to December were the two spring periods, and the period from December to February was summer.

To extrapolate data to gaps in onsite weather data series, two strategies were followed. For the Pacific Northwest, weather data were lacking for the two first sampling dates because the data loggers only became available prior to the third sampling date. In this case, data resulting from the bilinear interpolation using
gridMed were used to perform correlations with the existing onsite weather data for the following parameters: mean, minimum and maximum daily temperatures, and $\mathrm{RH}$. Correlations in the maximum RH for all sites, mean RH for sites CAS and N04, and minimum RH for site N04 provided adjusted $R^{2}$ values $<0.40$ and were not used to predict values corresponding to the first two sampling dates. In New Zealand, complete weather data were available for four of the six sites; these data were used to interpolate a 4-week gap at site KIN and to extrapolate the initial 6-week gap at site MAM, with adjusted $R^{2}$ values $>0.52$.

Isolation and identification of $\boldsymbol{P}$. pluvialis. All Pacific Northwest samples were processed in the laboratory facilities of the Department of Botany and Plant Pathology (Oregon State University, Corvallis), and the New Zealand samples were processed in the Scion laboratories (New Zealand Forest Research Institute, Rotorua). Ten needles showing typical pale olive lesions (Gómez-Gallego et al. 2017) were selected to perform isolations targeting $P$. pluvialis. Needles with an active lesion margin presenting both symptomatic and asymptomatic tissue were targeted to favor those with active pathogen growth. When these conditions were not met, either asymptomatic or completely symptomatic needles were selected. Five of the 10 needles were surface-sterilized for $10 \mathrm{~s}$ in $5 \%$ sodium hypochlorite, rinsed with sterilized distilled water, and plated onto selective corn-based agar media (10 mg/liter of pimaricin, $200 \mathrm{mg} /$ liter of ampicillin, $10 \mathrm{mg} / \mathrm{liter}$ of rifampicin); the other five needles were plated without sterilization to avoid possible pathogen loss with the sterilization step. Following the same criteria of symptomatology, another set of needles up to $\approx 125 \mathrm{mg}$ (wet weight) was placed in individual tubes and frozen at $-20^{\circ} \mathrm{C}$ until DNA extraction was performed.

Plates were kept at $17^{\circ} \mathrm{C}$ for up to 15 days, and growth was evaluated on a daily basis. Mycelium was collected from the growing colony margin and subcultured onto either carrot-based or corn-based agar without antibiotics. Subcultures were identified morphologically after 4 days to examine the hyphal swellings, sporangia, and oogonia as described by Reeser et al. (2013). In the absence of reproductive structures in culture, the isolates were placed in pond water to encourage sporulation (Erwin and Ribeiro 1996). The success or failure of $P$. pluvialis isolation was recorded for each tree, and the proportion of positive trees at each site was calculated.

DNA extractions and real-time quantitative PCR. Genomic DNA was extracted from frozen needle samples using the Nucleospin Plant II kit (Macherey-Nagel) in a 96-well plate format. DNA was extracted according to the method used for N96 (Telfer et al. 2013) with a slight modification in the volume of lysis buffer PL2, which was increased further [ $975 \mu \mathrm{l}$ of PL2 and $25 \mu \mathrm{l}$ of RNase A (total 1,000 $\mu \mathrm{l}$ )]. In Oregon, the final steps (DNA binding to the silica membrane and washing) were performed by centrifuging the plates instead of using the vacuum manifold. DNA extracts were quantified by spectrophotometry using NanoDrop (DeNovix DS-11 FX+ in New Zealand; ND-1000 UV-Vis Spectrophotometer in Oregon) to determine the absorbance of each sample at 230-, 260-, and 280-nm wavelengths. The ratios A260/A230 and A260/A280 were used to assess DNA quality and to detect organic compound and protein contamination, respectively. The 96-well plates containing the DNA extracts were diluted to 1:10 to perform the relative quantitative PCR (qPCR) for Douglas fir and $N$. gaeumannii and to $1: 2$ for P. pluvialis. The dilution rate was determined by performing qPCR for a subsample of DNA extracts.

The multiplex approach was ruled out because of variable reaction optima, the potential for PCR bias, and appreciably lower abundance of $P$. pluvialis detected in preliminary trials with respect to both $N$. gaeumannii and Pseudotsuga menziesii (Bustin et al. 2009). Therefore, we approached the relative quantification of each pathogen by running the assays in simplex. The probe and primer pairs used and the single copy target gene for each organism are listed in Table 1. All qPCRs were performed in a total volume of $20 \mu \mathrm{l}$ containing $5 \mu \mathrm{l}$ of template DNA, $10 \mu \mathrm{l}$ of PerfeCTa qPCR 
Tough Mix (Quantabio), $150 \mathrm{nM}$ of probe, and $400 \mathrm{nM}$ of each primer. In Oregon, qPCRs were performed using the CFX96 Touch Real-Time PCR Detection Systems (Bio-Rad). In New Zealand, the QuantStudio 6 Flex Real-Time PCR System (Thermo Fisher Scientific) was used. Both systems processed 96-well plates. Reaction conditions for Douglas fir and $N$. gaeumannii were as follows: $10 \mathrm{~min}$ at $50^{\circ} \mathrm{C}, 5 \mathrm{~min}$ at $95^{\circ} \mathrm{C}$, and 40 cycles of $95^{\circ} \mathrm{C}$ for $15 \mathrm{~s}$ and $60^{\circ} \mathrm{C}$ for $1 \mathrm{~min}$ (Winton et al. 2002). For P. pluvialis, reaction conditions were as follows: $10 \mathrm{~min}$ at $95^{\circ} \mathrm{C}$ and 45 cycles of $96^{\circ} \mathrm{C}$ for $15 \mathrm{~s}$ and $60^{\circ} \mathrm{C}$ for $1 \mathrm{~min}$ (R. McDougal, unpublished data). The cycle threshold $(\mathrm{Cq})$ values for each reaction were calculated automatically using the associated software (CFX manager software v3.1.1517.0823 and QuantStudio Real-Time PCR software v1.3).

Standard curves were constructed by amplifying DNA from the three target species: Douglas fir, $N$. gaeumannii, and $P$. pluvialis. Total DNA was serially diluted 10 -fold with sterile PCR-grade water. In different plates, two standard curves were performed for each target species. Three technical replicates were run per dilution level. Linear regressions were performed between log-transformed DNA concentrations and $\mathrm{Cq}$ using the software $\mathrm{R}$ version 3.5.1 (R Core Team 2017). Coefficients of determination $\left(R^{2}\right)$ obtained from linear regression for $N$. gaeumanni, $P$. pluvialis, and Douglas fir standard curves were $0.99,0.99$, and 0.96, respectively, in Oregon and 0.94, 0.97 , and 0.97 , respectively, in New Zealand. In every qPCR assay, we included two technical replicates of the DNA positive controls used for standard curves (1:10 dilution), and water replaced the template DNA for negative controls (two replicates). The maximum $\mathrm{Cq}$ value obtained for the average standard curve was considered the limit of detection for the corresponding target species. Cq values exceeding these thresholds were considered false-positive results.

Pathogen-to-host DNA ratios were used to analyze the relative abundance of each pathogen. $N$. gaeumannii has often been assessed by the pseudothecia density present on needles, which provides a direct link to the physiological impact on the plant (Hansen et al. 2000; Manter et al. 2000, 2003). However, quantification by qPCR has been highly correlated to pseudothecia density and levels of disease severity in the field (Winton et al. 2003). Furthermore, qPCR allows direct comparisons with P. pluvialis, for which no alternative quantification methods based on fruiting structures have previously been implemented. To allow unbiased comparisons, ratios of $P$. pluvialis and $N$. gaeumannii DNA concentrations to Douglas fir DNA concentrations were calculated (hereafter referred to as $P$. pluvialis abundance and $N$. gaeumannii abundance, respectively). To obtain these ratios, standard curves were used to approximate the concentration (in ng/ $\mu l)$ for each species and sample. The proportion of $P$. pluvialis and
$N$. gaeumannii positive $\mathrm{qPCR}$ analyses at each site was also calculated (proportion of infected trees).

Data analysis. All statistical analyses were conducted using the software R version 3.5.1 (R Core Team 2017). For the sampling data obtained every 2 weeks, we used generalized additive mixed models (GAMMs) and a flexible semi-parametric method to characterize nonlinear relationships and one or more explanatory variables. Pathogen-to-host DNA ratios were averaged for each site and modeled using GAMM with a tweedie error distribution family (function gamm, package mgcv; Wood 2017) (equations 1 and 2). Equations are provided for best-fit models after backward selection from saturated models.

Equation 1. Best-fit GAMM for the P. pluvialis DNA ratio as a response variable for the sampling data obtained every 2 weeks.

$$
\begin{aligned}
\text { Ppratio }_{i} & =\beta_{0}+\beta_{1} \text { country }_{i}+\beta_{2} G D D_{i} \\
& +\beta_{3} \text { GDD }_{i} * \text { country }_{i}+\beta_{4} \text { Ngratio }_{i} \\
& +u \cdot \text { site }_{i} / \text { country }_{i}+\epsilon_{i}
\end{aligned}
$$

where the P. pluvialis abundance of tree $i\left(\right.$ Ppratio $\left._{i}\right)$ is modeled as a linear function of the country, growing degree days at the moment of sampling $\left(G D D_{i}\right)$ and its interaction with country $\left(G D D_{i} *\right.$ country $\left._{i}\right)$, and $N$. gaeumannii abundance $\left(\right.$ Ngratio $\left._{i}\right)$. In this model and subsequent models, 'country' nested within 'site' was incorporated as a random effect ( site $_{i} /$ country $_{i}$ ) to account for repeated measures, and $\epsilon_{i}$ corresponds to the residual error.

Equation 2. Best-fit GAMM for the $N$. gaeumannii DNA ratio as a response variable for the sampling data obtained every 2 weeks.

$$
\begin{aligned}
\text { Ngratio }_{i} & =\beta_{0}+s\left(\text { RH }_{\text {spring }, i} * \text { country }_{i}\right) \\
& +\beta_{1} \text { country }_{i}+\beta_{2} T_{\text {winter }, i}+\beta_{3} T_{\text {winter }, i} * \text { country }_{i} \\
& +u \cdot \text { site }_{i} / \text { country }_{i}+\epsilon_{i}
\end{aligned}
$$

where the $N$. gaeumannii abundance of tree $i\left(\right.$ Ngratio $\left._{i}\right)$ is modeled as a smooth function $(s)$ of the mean relative humidity of the previous spring $\left(R H_{\text {spring }, i}\right)$, country, and mean temperature of the previous winter $\left(T_{\text {winter }, i}\right)$.

The proportion of $P$. pluvialis-infected trees was modeled in a similar manner using a binomial error distribution following equation 3 .

TABLE 1. TaqMan probe, primer sets, and target genes for relative quantification of Nothophaeocryptopus gaeumannii and Phytophthora pluvialis in DNA extracts of Douglas fir (Pseudotsuga menziesii) needles

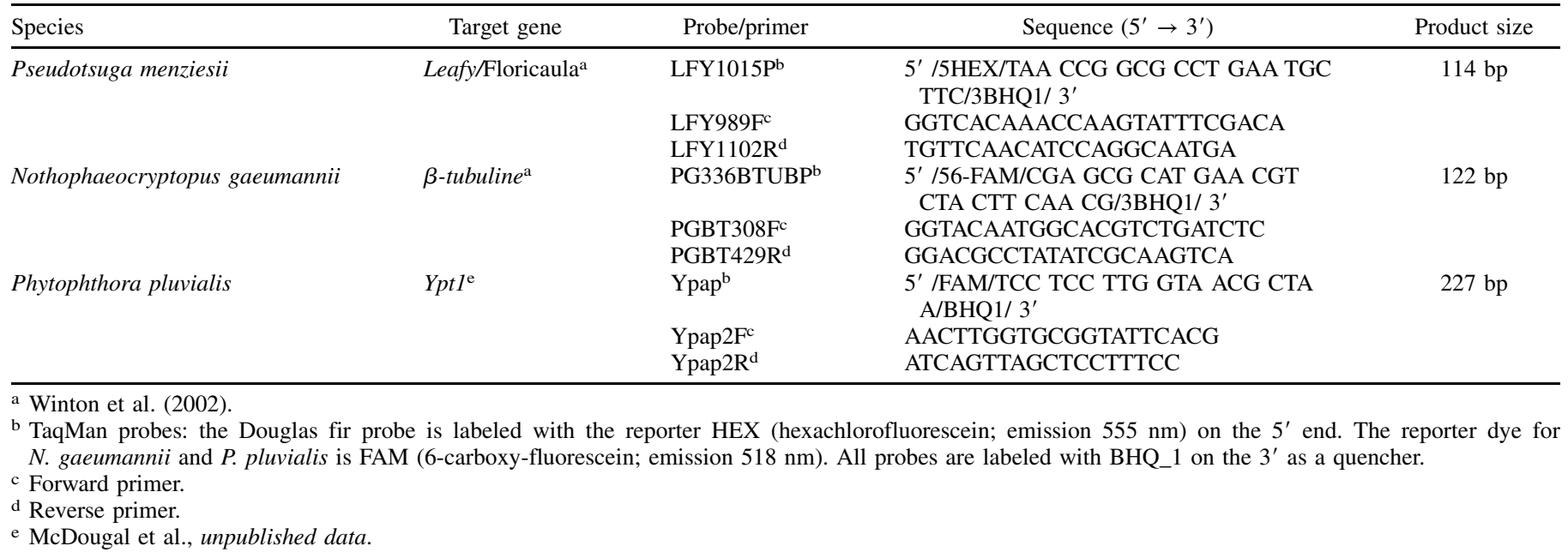


Equation 3. Best-fit GAMM for the proportion of $P$. pluvialisinfected trees as a response variable for the sampling data obtained every 2 weeks.

$$
\begin{aligned}
\text { Ppinfected }_{i} & =\beta_{0}+\beta_{1} \text { country }_{i}+\beta_{2} G D D_{i} \\
& +\beta_{3} R H_{i}+\beta_{4} R H_{i} * \text { country }_{i} \\
& +u \cdot \text { site }_{i} / \text { country }_{i}+\epsilon_{i}
\end{aligned}
$$

where Ppinfected $_{i}$ is the proportion of infected trees at each site and $\mathrm{RH}$ is the mean daily relative humidity.

For the regional data, we used the same family distributions. However, because there were no repeated measures involved, we ran the generalized additive models (GAM) without a random term (function gam, R package mgcv; Wood 2011). Model formulations for the same response variables used for the sampling performed every 2 weeks (equations 1,2, and 3) are in equations 4, 5, and 6 for regional sampling.

Equation 4. Best-fit GAM for the P. pluvialis DNA ratio as a response variable for the regional sampling data.

$$
\begin{aligned}
\text { Ppratio }_{i} & =\beta_{0}+\beta_{1} \text { country }_{i}+\beta_{2} \text { Ngratio }_{i} \\
& +\beta_{3} \text { Ngratio }_{i} * \text { country }_{i}+\beta_{4} R H_{\text {winter }, i} \\
& +\beta_{5} \text { RH }_{\text {winter } i} * \text { country }_{i}+\epsilon_{i}
\end{aligned}
$$

where $R H_{\text {winter }, i}$ is the mean relative humidity of the previous winter.

Equation 5. Best-fit GAM for the N. gaeumannii DNA ratio as a response variable for the regional sampling data.

$$
\begin{aligned}
\text { Ngratio }_{i} & =\beta_{0}+\beta_{1} \text { country }_{i}+\beta_{2} T_{\text {winter }_{i}} \\
& +\beta_{3} T_{\text {winter }_{i}} * \text { country }_{i}+\beta_{4} \text { Ppratio }_{i} \\
& +\beta_{5} \text { Ppratio }_{i} * \text { country }_{i}+\epsilon_{i}
\end{aligned}
$$

Equation 6. Best-fit GAM for the proportion of the P. pluvialisinfected trees as a response variable for the sampling data obtained every 2 weeks.

$$
\text { Ppinfected }_{i}=\beta_{0}+s\left(R H_{\text {winter }, i}\right)+\beta_{1} \text { country }_{i}+\beta_{2} G D D_{i}+\epsilon_{i}
$$

Backward model selection was used to determine the optimal smoothers and parametric terms of the GAMs using the Akaike Information Criterion (AIC). To reduce the large number of explanatory variables, the microclimatic site variables were grouped into three groups depending on the variable they were derived from (temperature, RH, and GDD). Seasonal climatic variables were grouped by temperature, $\mathrm{RH}$, and precipitation and by winter or spring (two spring periods considered and summer). The saturated model was run with one variable from each group, and a comparison between AIC was considered to choose the best

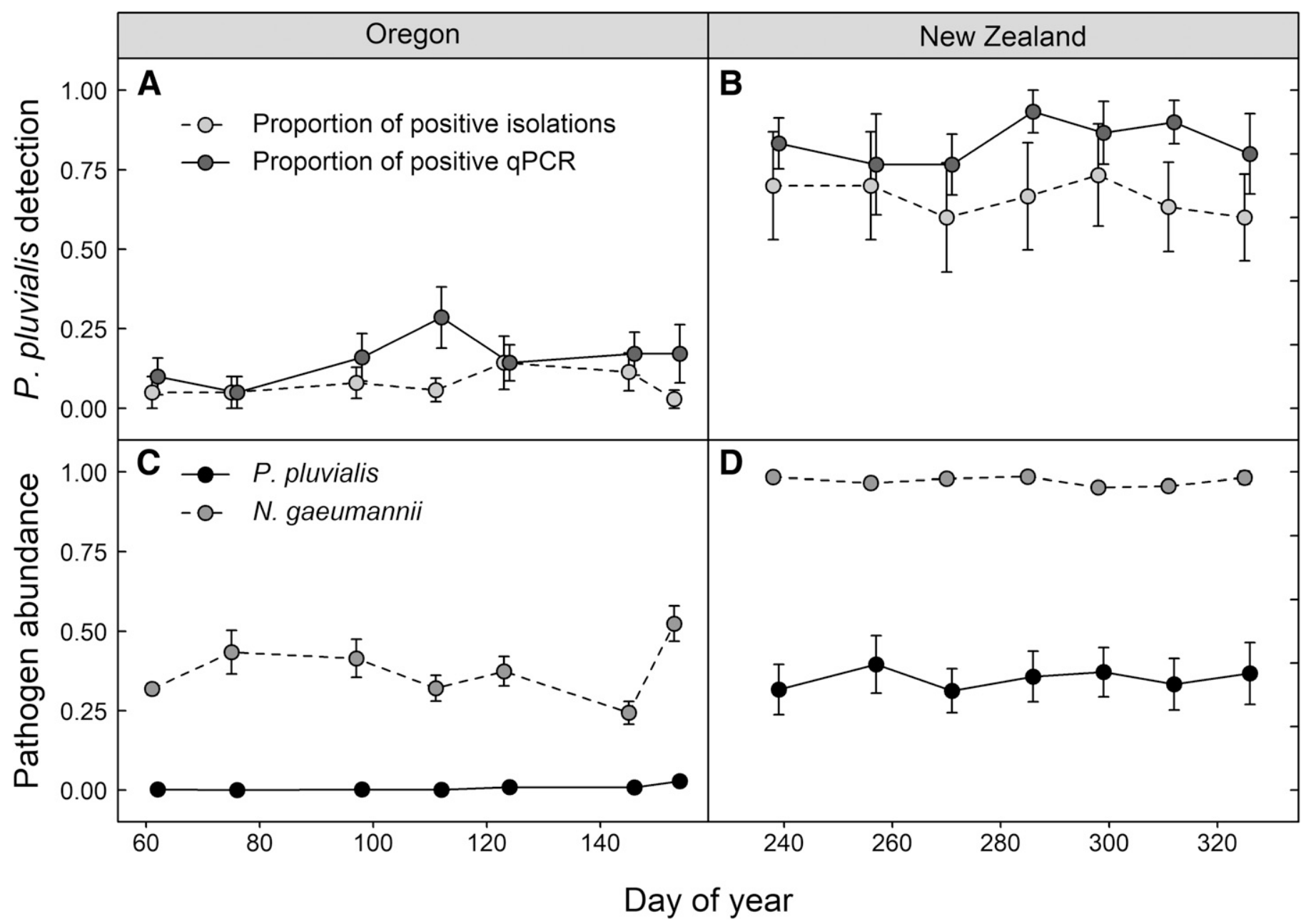

Fig. 1. Phytophthora pluvialis detection rates by means of isolation in culture media and qPCR in A, Oregon and B, New Zealand, and pathogen abundance, measured as pathogen-to-host DNA ratio, for P. pluvialis and Nothophaeocryptopus gaeumannii in $\mathbf{C}$, Oregon and D, New Zealand over time obtained during the 3-month spring sampling performed every 2 weeks. 
explanatory variable of each group. Climatic variables on a continuous scale were included in the smoother term of the GAMs, whereas the binary variables were included in the parametric term. $P$. pluvialis abundance was included in the smoother term of the model for $N$. gaeumannii abundance as a response variable, and vice versa. Country was included in the parametric term, and its interaction with the climatic variables was also tested (i.e., whether separate smoothers for each country were warranted).
Significant variables showing a linear pattern were included in the parametric term. Concurvity was analyzed to detect possible collinearity among predictors, and no collinearity was detected among predictors of the best-fitted models. Graphical model validation tools (residual plots for variance homogeneity and quantile-quantile plots for normality) were used to assess the underlying model assumptions and suitability of chosen error distributions.

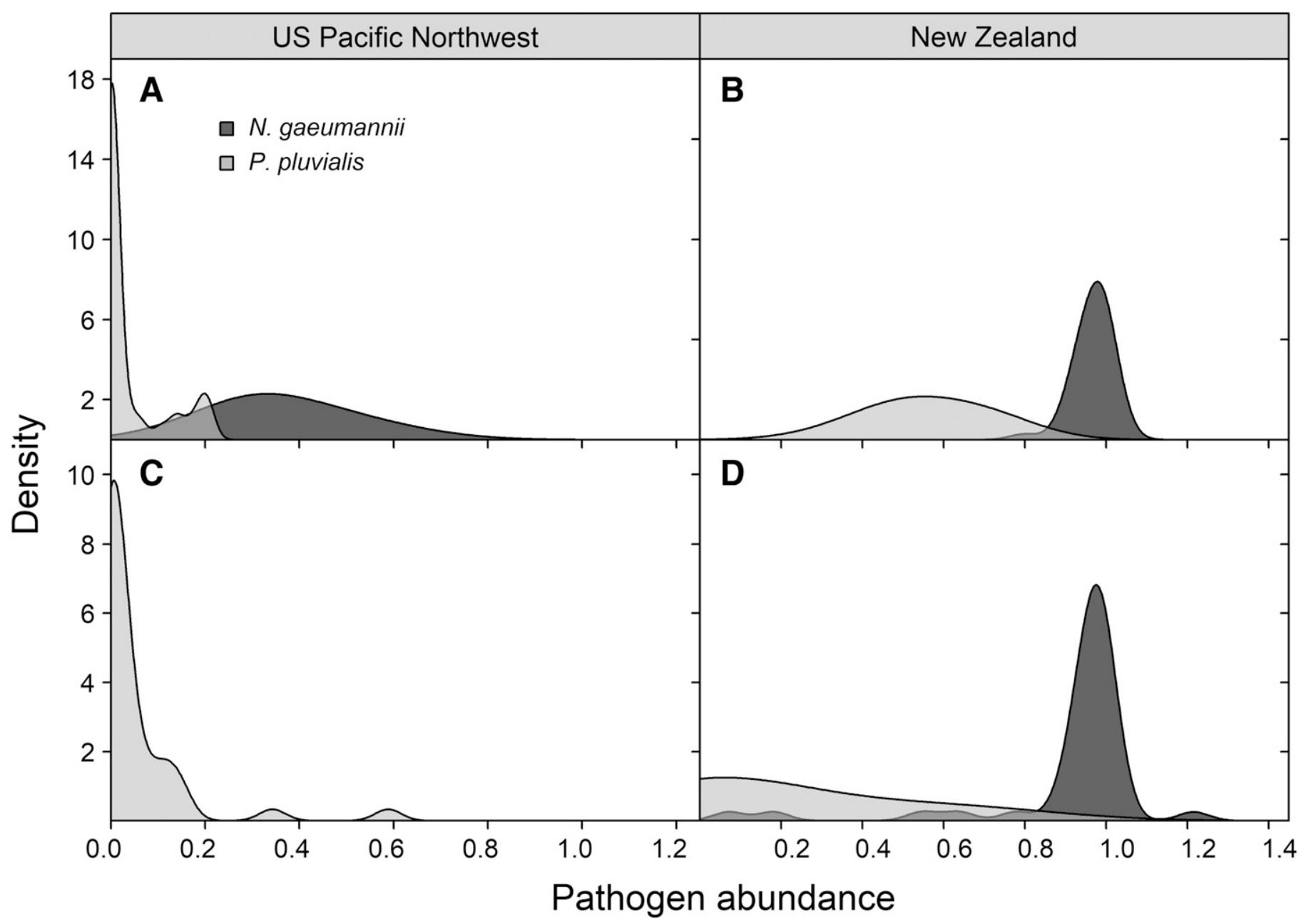

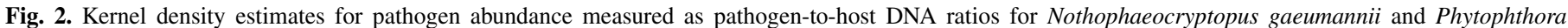

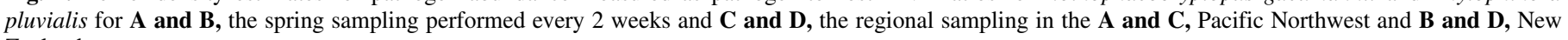
Zealand.

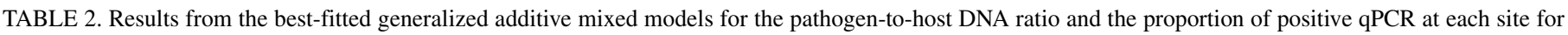
the sampling every 2 weeks ${ }^{\mathrm{a}}$

\begin{tabular}{|c|c|c|c|c|c|c|c|c|c|}
\hline \multirow[b]{2}{*}{ Parametric coefficients } & \multicolumn{3}{|c|}{$\begin{array}{l}P . \text { pluvialis abundance Family: } \\
\text { tweedie (1.45); Link: } \log R^{2} \text { adj. } 0.86\end{array}$} & \multicolumn{3}{|c|}{$\begin{array}{l}\text { Proportion of } P \text {. pluvialis-infected trees } \\
\text { Family: binomial; Link: logit } R^{2} \text { adj. } 0.90\end{array}$} & \multicolumn{3}{|c|}{$\begin{array}{l}N . \text { gaeumannii abundance Family: } \\
\text { tweedie (1.01); Link: } \log R^{2} \text { adj. } 0.93\end{array}$} \\
\hline & Estimate (SE) & $t$ & $P$ & Estimate (SE) & $t$ & $P$ & Estimate (SE) & $t$ & $P$ \\
\hline Intercept & $-3.18(0.50)$ & -6.34 & $<0.001$ & $-8.68(3.49)$ & -2.49 & 0.02 & $-3.74(0.60)$ & -6.23 & $<0.001$ \\
\hline Country & $-0.43(0.79)$ & 0.54 & 0.59 & $18.15(5.19)$ & 3.50 & $<0.001$ & $3.74(0.61)$ & -6.11 & $<0.001$ \\
\hline GDD & $-0.01(0.01)$ & -2.32 & 0.02 & $0.01(0.01)$ & 2.38 & 0.02 & & & \\
\hline GDD $\times$ country & $0.02(0.01)$ & 2.62 & 0.01 & & & & & & \\
\hline N. gaeumannii abundance & $2.06(1.14)$ & 1.81 & 0.075 & & & & & & \\
\hline Mean daily RH & & & & $0.07(0.04)$ & 1.70 & 0.09 & & & \\
\hline Mean daily $\mathrm{RH} \times$ country & & & & $-0.16(0.06)$ & -2.72 & 0.01 & & & \\
\hline Mean winter $\mathrm{T}$ & & & & & & & $0.66(0.14)$ & 4.71 & $<0.001$ \\
\hline Mean winter $\mathrm{T} \times$ country & & & & & & & $-0.67(0.14)$ & -4.73 & $<0.001$ \\
\hline Smooth terms & edf & $\mathrm{F}$ & $P$ & edf & chi-square & $P$ & edf & $\mathrm{F}$ & $P$ \\
\hline s (mean spring $\mathrm{RH}$ ): OR & & & & & & & 3.71 & 18.60 & $<0.001$ \\
\hline $\mathrm{s}$ (mean spring $\mathrm{RH})$ : NZ & & & & & & & 1 & 0.20 & 0.66 \\
\hline
\end{tabular}

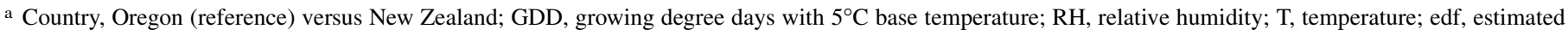
degrees of freedom; s, smoother term; OR, Oregon; and NZ, New Zealand. SE, standard error. 


\section{RESULTS}

Sampling every 2 weeks. Both $P$. pluvialis and N. gaeumannii were consistently more abundant in New Zealand than in the Pacific Northwest (Fig. 1, Fig. 2A and B). In New Zealand, more trees tested positive for $P$. pluvialis from the cultured needle samples (10 needles/sample) across all dates (69 vs. $7 \%$ in New Zealand and Oregon, respectively). These results paralleled detection rates by qPCR, with 85 and $15 \%$ for New Zealand and Oregon, respectively. The abundance of both pathogens (pathogen-to-host DNA ratio) was greater in New Zealand than in Oregon, with mean $P$. pluvialis abundance of 0.36 and 0.008 , respectively (Fig. 1C and D). Similarly, $N$. gaeumannii abundance was greater in New Zealand than in Oregon (0.97 vs. 0.37, respectively) (Fig. 1C and D). Regardless of the country, $N$. gaeumannii was significantly more abundant than $P$. pluvialis. Even though the amounts of $N$. gaeumannii DNA present in the needles were different between the countries, the proportion of $N$. gaeumannii-infected trees was similar (average values of 0.99 versus 0.95 for New Zealand and Oregon, respectively). With very few exceptions, SNC was detected in all trees in the sampling performed every 2 weeks.

$P$. pluvialis detection by $\mathrm{qPCR}$ exceeded or equaled isolation rates and was considered more effective for assessing $P$. pluvialis infection. Isolation results corroborated the validity of qPCR in both laboratories (Fig. 1A and B). In New Zealand, N. gaeumannii infection lacked a seasonal pattern and had an average DNA ratio of $0.97( \pm 0.01)$ (Fig. 1D). In the Pacific Northwest, the infection of both pathogens varied across the 3-month sampling period, with $P$. pluvialis peaking in mid-spring (last week of April), whereas $N$. gaeumannii reached the maximum abundance at the beginning of summer (Fig. 1C).

The GAMMs accounted for at least $86 \%$ of the total variation in $N$. gaeumannii and P. pluvialis abundance and the proportion
P. pluvialis-infected trees. Only in the Pacific Northwest was the seasonality of $P$. pluvialis models captured by the GDD (Table 2, Fig. 3). N. gaeumannii abundance was positively correlated with $P$. pluvialis abundance in both countries (Table 2). In both countries, the proportion of $P$. pluvialis-infected trees increased with increasing GDD, and this effect was statistically significant (Table 2). N. gaeumannii abundance appeared to have no effect on the proportion of $P$. pluvialis-infected trees, but the mean daily RH was significant and had a significant interaction with country (Table 2). In the Pacific Northwest, an increase in the daily $\mathrm{RH}$ resulted in an increase in the proportion of $P$. pluvialis-infected trees, whereas the opposite effect was observed in New Zealand. $N$. gaeumannii abundance was explained by the mean winter temperature and spring RH (April to June, Pacific Northwest), which were significant only for the Pacific Northwest (Table 2).

Scanning electron microscope micrographs showed the growth of both $N$. gaeumannii and $P$. pluvialis on the surfaces of Douglas fir needles (Fig. 4). Clusters of P. pluvialis sporangia and N. gaeumanni occupied neighboring stomata on the same needles (Fig. 4A to C). The samples were collected on the last day of southern hemisphere winter (31 Aug. 2017) on the North Island (sites Z1 and Z2). At that time, fruiting bodies of the two pathogens were developing within the same needles. Early release of $N$. gaeumannii ascospores and mature pseudothecia were observed on some of the needles (Fig. 4E and F).

Regional sampling. Aggregated results from all sites for the regional sampling led to results similar to those for sampling performed every 2 weeks. P. pluvialis and N. gaeumannii were more abundant in New Zealand than in the Pacific Northwest, with average values of 0.20 and 0.91 compared to 0.05 and 0.36 , respectively (Fig. 2C and D). Although $N$. gaeumannii was detected by qPCR in all the sampled trees in both New Zealand and the Pacific Northwest, P. pluvialis was present in 47 and $20 \%$ of the
A

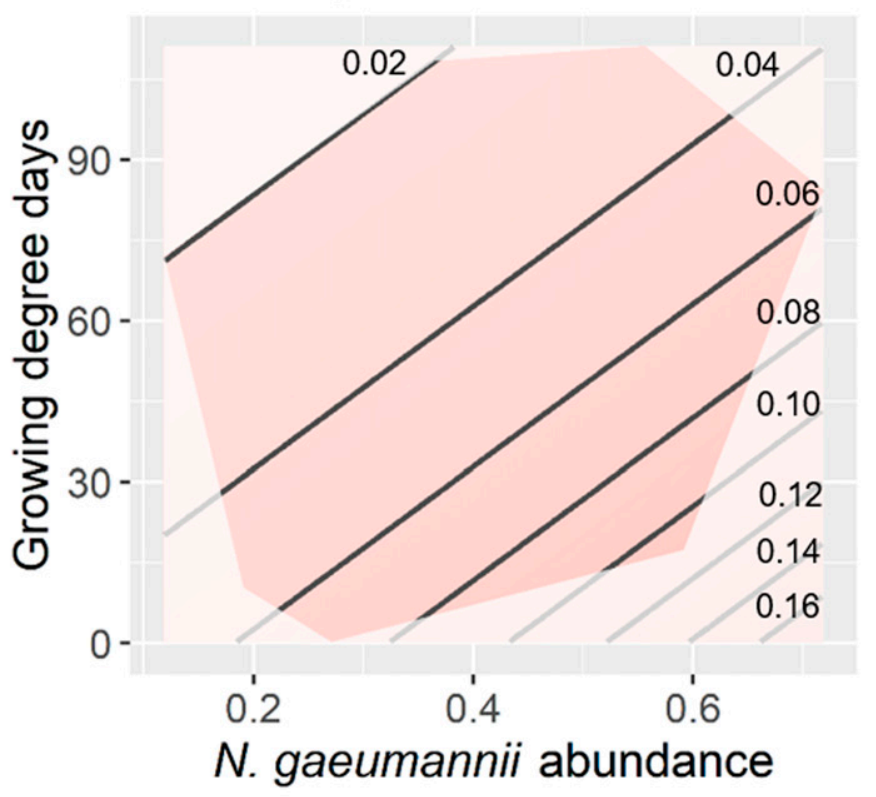

B New Zealand

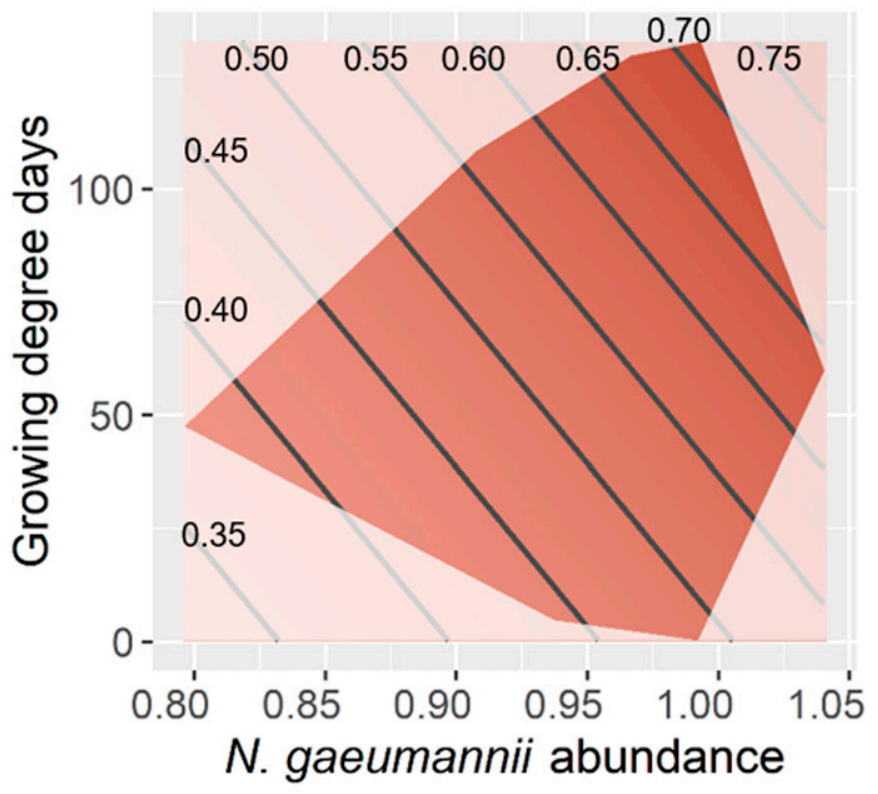

\section{P. pluvialis abundance}

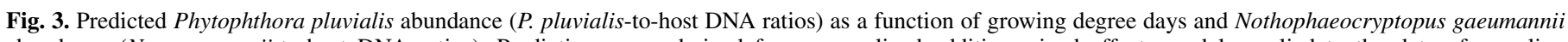

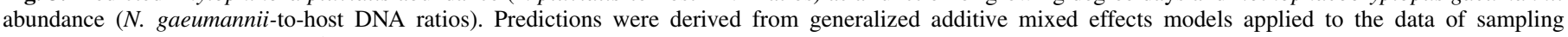

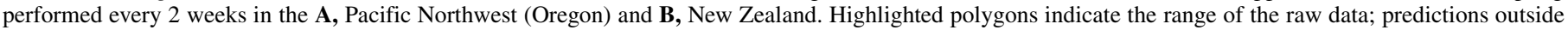
this range should not be considered. Both axis variables are statistically significant except for the $y$-axis (growing degree days) in panel $\mathbf{B}$. 
trees, respectively. The regional distributions of values for normalized $N$. gaeumannii and P. pluvialis abundance (pathogen-to-host DNA ratios) are shown in Figure 5.

When analyzing the proportion of infected trees at the regional level, the comparison between a GAMM with a common smoother for the mean winter RH for both New Zealand and the Pacific Northwest and a GAM with separate smoothers for both countries lent support to the latter, suggesting a mean winter $\mathrm{RH} \times$ country interaction $(L=4.34$; df $=0.91 ; P=0.03)$. In New Zealand, $P$. pluvialis abundance increased significantly with higher mean
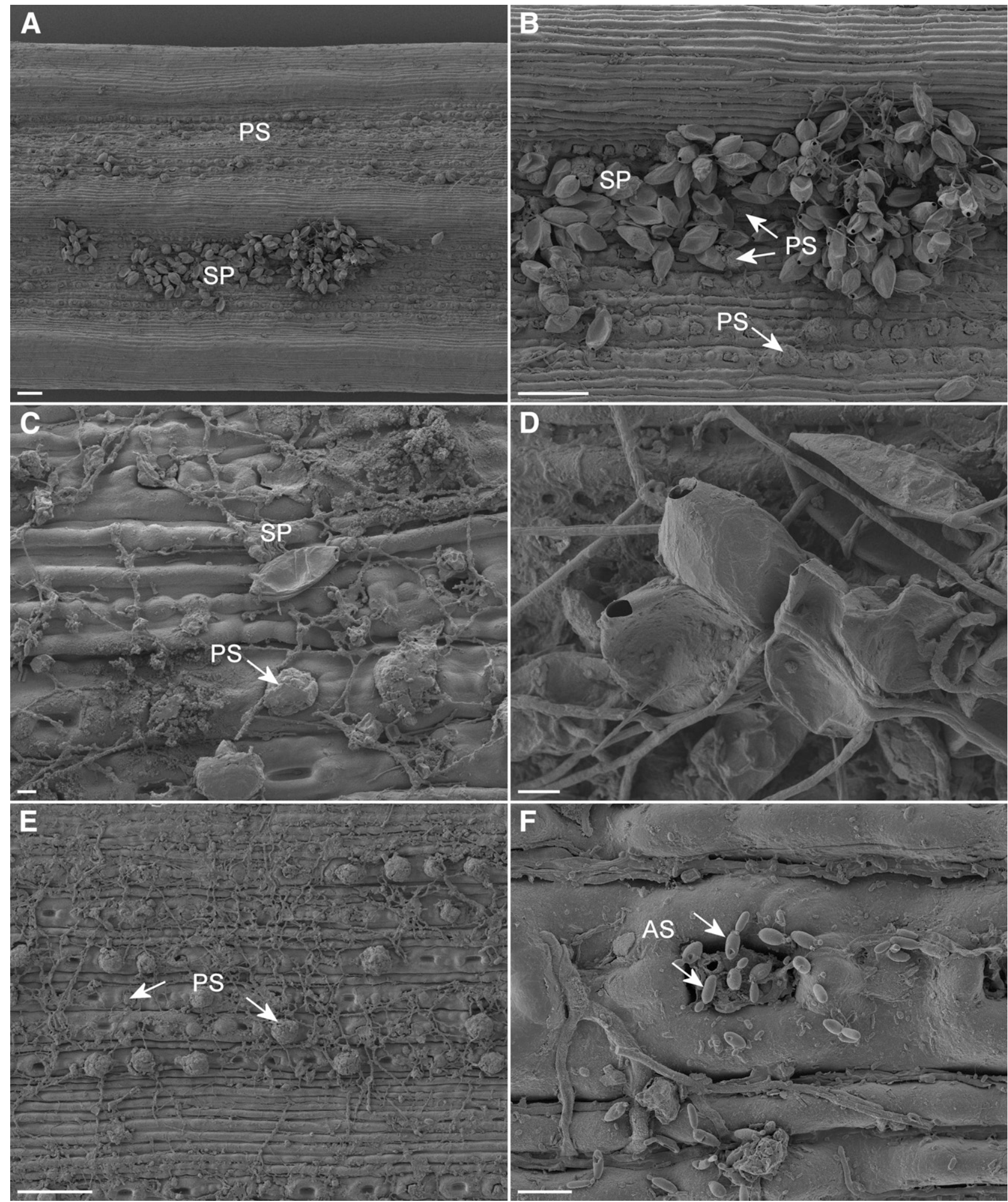

Fig. 4. Scanning electron micrographs showing fruiting bodies of A, B, C, and D, Phytophthora pluvialis and A, B, C, E, and F, Nothophaeocryptopus gaeumannii on Douglas fir needles sampled on 31 August 2017 in New Zealand. A, Occupation of needle stomata by N. gaeumannii pseudothecia (PS) and clusters of $P$. pluvialis sporangia (SP). B, Details of neighboring P. pluvialis sporangia and N. gaeumannii pseudothecia at different stages of maturity. C, Details of an empty sporangia next to a mature pseudothecium. D, Details of discharged P. pluvialis sporangia. E, N. gaeumannii hyphae and pseudothecia at different stages of maturity. F, N. gaeumannii ascospores (AS) being released from mature asci. Bars: A, B, and $\mathbf{E}=100 \mu \mathrm{m} ; \mathbf{C}, \mathbf{D}$, and $\mathbf{F}=10 \mu \mathrm{m}$. 
winter RH (Table 3, Fig. 6B). The number of $P$. pluvialis-infected trees increased significantly with increasing GDD (Table 3) $(P<$ 0.001 ), irrespective of the country.

Mean winter RH showed a linear positive correlation with $P$. pluvialis abundance in New Zealand, but not in the Pacific Northwest (Table 3, Fig. 6B). Therefore, N. gaeumannii abundance only explained the variation in $P$. pluvialis abundance in the Pacific Northwest, but not in New Zealand. Remarkably, higher P. pluvialis abundance was predicted with lower levels of $N$. gaeumannii in the Pacific Northwest (Table 3, Fig. 6A). In addition, when $N$. gaeumannii abundance was modeled at the regional level, lower P. pluvialis abundance resulted in higher levels of $N$. gaeumannii. The mean winter temperature explained a significant proportion of the variation seen in $N$. gaeumannii abundance, but only in the Pacific Northwest, and, surprisingly, as an inverse correlation (Table 3, Fig. 6B).

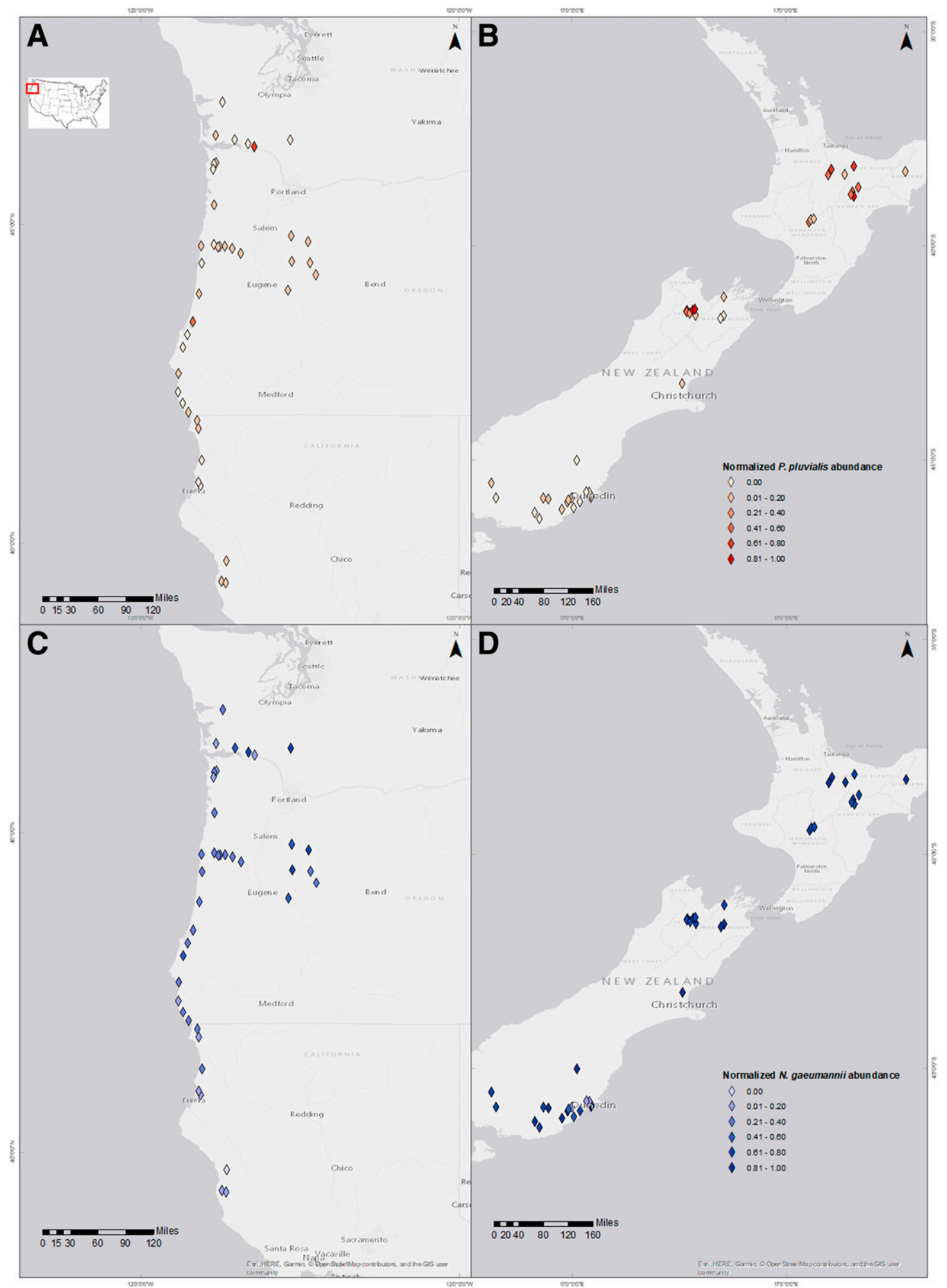

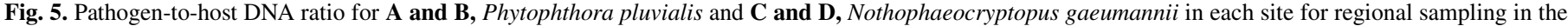
$\mathbf{A}$ and C, Pacific Northwest and $\mathbf{B}$ and D, New Zealand. Ratios are normalized in the 0 to 1 range to be comparable across countries and pathogens. 


\section{DISCUSSION}

With the recent emergence of $P$. pluvialis as a pathogen causing early defoliation of Douglas fir, the aim of this study was to investigate the extent of the epidemic in both countries (New Zealand and the Pacific Northwest) and the interaction of $P$. pluvialis with $N$. gaeumannii. Our results showed the coexistence of both $N$. gaeumannii and $P$. pluvialis across spatial scales for regions and needles. Furthermore, an inverse correlation was observed between the relative abundance of the two pathogens in the Pacific Northwest, where they have likely co-existed for longer.

$P$. pluvialis epidemics and seasonality. Our data demonstrated that $P$. pluvialis infects the lower canopy of Douglas fir in both countries (Fig. 1). In New Zealand, P. pluvialis was more abundant in the North Island and decreased gradually toward the south of the South Island (Fig. 5B). Mean winter RH (June to August previous to the sampling period) was the only significant climatic factor explaining the variation in the relative abundance of $P$. pluvialis in New Zealand. P. pluvialis has caducous sporangia, which are produced on the surface of infected needles (Hansen et al. 2017; Reeser et al. 2013), releasing zoospores under conditions of high RH that are disseminated by water splash (Dick et al. 2014). The positive correlation between winter $\mathrm{RH}$ and $P$. pluvialis abundance suggested that active inoculum build-up occurs during winter months and is favored by high RH values in New Zealand. In contrast, this effect was not found in the Pacific Northwest. A lower nonoverlapping range in winter $\mathrm{RH}$ was recorded in the Pacific Northwest, suggesting that low RH limits $P$. pluvialis inoculum production.

The most likely explanation for the limited presence of $P$. pluvialis in the south of the South Island could be a later arrival of the pathogen because the previous two $P$. pluvialis population clusters were found in the North Island and the north of the South Island (Brar et al. 2018). It is possible that when the sampling was performed, the pathogen population had not yet reached a steady state. Suboptimal conditions for disease development within tree canopies also could have slowed inoculum development, although our climatic variable analysis did not support this conclusion.

The great abundance of $P$. pluvialis in New Zealand samples could also be explained by high inoculum loads originating from infected trees in surrounding radiata pine plantations. In New Zealand, $P$. pluvialis in radiata pine had been noted to have cyclical epidemics every 2 to 3 years (Ganley et al. 2014); however, these cycles are less evident in areas where the pathogen is well-established and the total needle compliment is reduced by successive casting events. Plantation forestry in New Zealand is dominated by $P$. radiata, which is the most widely planted species; it occupies $90 \%$ of the planted area. Therefore, the epidemiology of $P$. pluvialis in Douglas fir may be linked to that in radiata pine because both host species can contribute to the inoculum build-up.

The results of sampling every 2 weeks suggested different infection dynamics between countries, probably related to the temperature response of the pathogen. The sampling design was based on prior knowledge of $P$. pluvialis epidemiology of radiata pine in New Zealand. The infection cycle typically begins in autumn, with peaks in winter and early spring, leading to defoliation of the symptomatic portion of the canopy during the subsequent summer (Dick et al. 2014). Our sampling every 2 weeks was designed to cover the spring season, guaranteeing P. pluvialis activity, because $N$. gaeumannii is detectable all year.

The proportion of infected trees increased with increasing GDD (Table 2), suggesting that disease epidemics developed during spring in both countries. However, P. pluvialis abundance decreased with increasing GDD in the Pacific Northwest (Table 2, Fig. 3A), but no effect was observed in New Zealand. This inverse correlation may be partially explained by the small amount of inoculum available in the Pacific Northwest compared with New Zealand. In New Zealand, $P$. pluvialis infection progresses through winter, allowing for a longer period of inoculum build-up; however, in the Pacific Northwest, winter appears to be a limiting period for $P$. pluvialis development. The mean daily winter temperature was lower in the Pacific Northwest compared with New Zealand (Pacific Northwest: 1.8 to $6.8^{\circ} \mathrm{C}$, December 2016 to February 2017; New Zealand: 6 to $9.6^{\circ} \mathrm{C}$, June to August 2017). Such differences may explain differences between the two countries in combination with other factors, such as the presence of alternative hosts (i.e., P. radiata in New Zealand). An absence of Douglas fir beneficial mutualists in the exotic environment of New Zealand may have a role in decreased host resilience and increased vulnerability to pathogen attack (Dickie et al. 2017). The relative contributions of climate variables and the features derived from an exotic environment cannot be disentangled from the analyses presented here and should be investigated further.

Differences in the interaction between $P$. pluvialis and N. gaeumannii in the Pacific Northwest and New Zealand. One of our most interesting findings was the inverse relationship between the abundance of the two pathogens in the Pacific Northwest (Table 3, Fig. 6A and C). This correlation could be explained by a potential lack of alternative hosts (Pinus radiata in

TABLE 3. Results from the best-fitted generalized additive models for the pathogen-to-host DNA ratio and the proportion of positive qPCR at each site for the regional sampling ${ }^{\mathrm{a}}$

\begin{tabular}{|c|c|c|c|c|c|c|c|c|c|}
\hline \multirow[b]{2}{*}{ Parametric coefficients } & \multicolumn{3}{|c|}{$\begin{array}{c}\text { P. pluvialis abundance } \\
\text { Family: tweedie (1.55); Link: } \\
\log R^{2} \text { adj. } 0.45\end{array}$} & \multicolumn{3}{|c|}{$\begin{array}{l}\text { Proportion of } P \text {. pluvialis-infected } \\
\text { trees Family: binomial; Link: } \\
\text { logit } R^{2} \text { adj. } 0.57\end{array}$} & \multicolumn{3}{|c|}{$\begin{array}{l}\text { N. gaeumanni abundance } \\
\text { Family: tweedie }(1.28) \text {; } \\
\text { Link: } \log R^{2} \text { adj. } 0.69\end{array}$} \\
\hline & Estimate (SE) & $t$ & $P$ & Estimate (SE) & $t$ & $P$ & Estimate (SE) & $t$ & $P$ \\
\hline Intercept & $0.52(6.69)$ & 0.08 & 0.94 & $-4.68(1.11)$ & -4.21 & $<0.001$ & $-0.38(0.16)$ & -2.30 & 0.02 \\
\hline Country & $-59.95(10.71)$ & -5.59 & $<0.001$ & $-7.24(9.68)$ & -0.75 & 0.45 & $0.18(0.26)$ & 0.71 & 0.48 \\
\hline $\mathrm{Ng}$ abundance & $-2.80(1.33)$ & -2.10 & 0.04 & & & & & & \\
\hline $\mathrm{Ng}$ abundance $\times$ country & $4.31(2.04)$ & 2.12 & 0.04 & & & & & & \\
\hline Mean winter RH & $-0.03(0.08)$ & -0.41 & 0.69 & & & & & & \\
\hline Mean winter $\mathrm{RH} \times$ country & $0.66(0.13)$ & 5.19 & $<0.001$ & & & & & & \\
\hline GDD & & & & $0.22(0.06)$ & 3.79 & $<0.001$ & & & \\
\hline Mean winter $T$ & & & & & & & $-0.14(0.04)$ & -3.89 & $<0.001$ \\
\hline Mean winter $\mathrm{T} \times$ country & & & & & & & $0.16(0.05)$ & 3.02 & 0.003 \\
\hline P. pluvialis abundance & & & & & & & $-1.84(0.82)$ & -2.24 & 0.03 \\
\hline P. pluvialis abundance $\times$ country & & & & & & & $2.02(0.84)$ & 2.39 & 0.02 \\
\hline Smooth terms & edf & $\mathrm{F}$ & $P$ & edf & chi-square & $P$ & edf & $\mathrm{F}$ & $P$ \\
\hline s (mean winter RH): OR & & & & 1.39 & 0.41 & 0.74 & & & \\
\hline $\mathrm{s}$ (mean winter $\mathrm{RH})$ : $\mathrm{NZ}$ & & & & 2.92 & 43.76 & $<0.001$ & & & \\
\hline
\end{tabular}

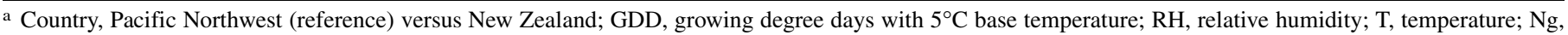
Nothophaeocryptopus gaeumannii; Pp, Phytophthora pluvialis; edf, estimated degrees of freedom; s, smoother term; OR, Oregon; and NZ, New Zealand. SE, standard error. 
New Zealand) serving as an inoculum source in the Pacific Northwest. Alternatively, it may be because of a longer period of competition between both pathogens in the Pacific Northwest. It is not known how long P. pluvialis has been present in the Pacific Northwest, and the origin of the species is unknown (Brar et al. 2018). However, the New Zealand population most likely originated from the population in the United States (Brar et al. 2018). This indicates that regardless of its origin, P. pluvialis and $N$. gaeumannii have co-existed for longer in the Pacific Northwest than in New Zealand.

Although SNC has been studied in the Pacific Northwest for some time, the association of $P$. pluvialis with Douglas fir is relatively recent (Reeser et al. 2013). However, it is likely that defoliation associated with $P$. pluvialis has been overlooked for some time and was perhaps attributed to SNC. The symptoms of $P$. pluvialis infection on Douglas fir are more difficult to detect than those on radiata pine because needles tend to cast when they are green or have a faint pale olive discoloration. The polycyclic nature of $P$. pluvialis reduces the window during which sporulating structures can be detected, unlike $N$. gaeumannii, which has pseudothecia that are visible throughout most of the year. Previous sampling methods to determine SNC severity have been based on mid-crown observations (Ritóková et al. 2016), which might have favored $N$. gaeumannii detection over $P$. pluvialis. In fact, the latter has been
A

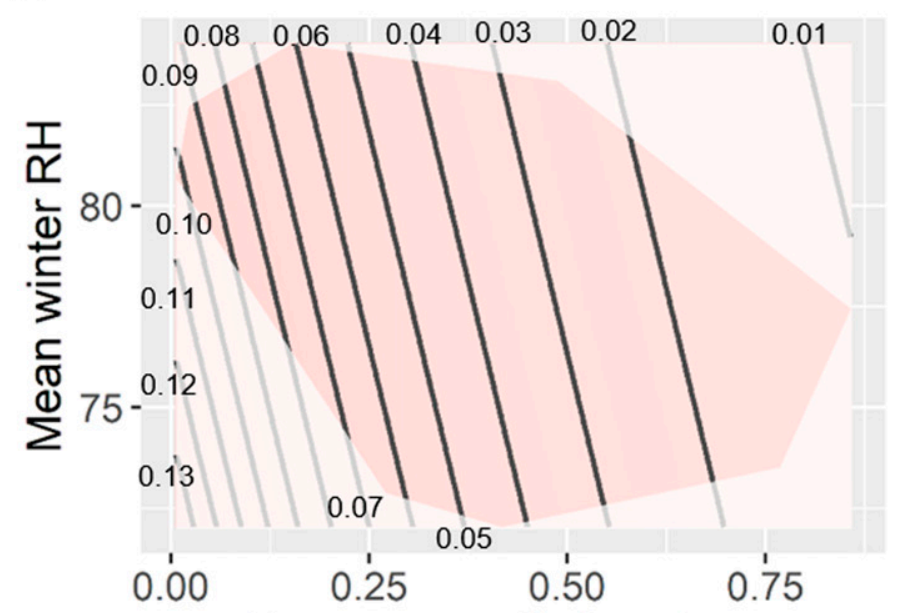

N. gaeumannii abundance

\section{$P$. pluvialis abundance}

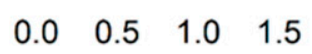

B New Zealand

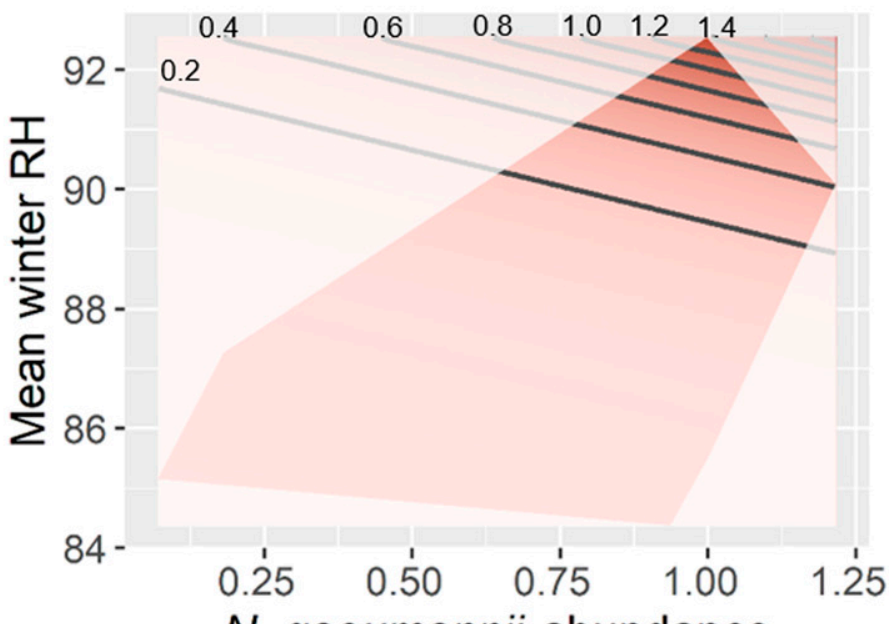

N. gaeumannii abundance

D New Zealand

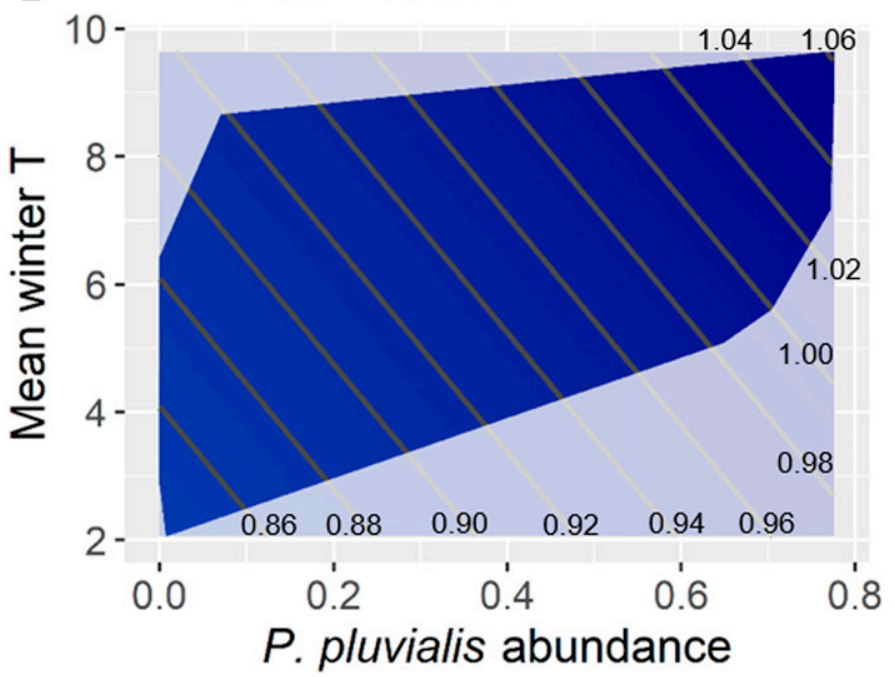

\section{N. gaeumannii abundance}

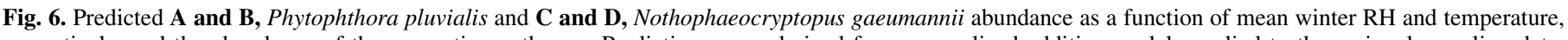

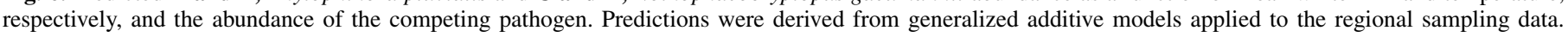

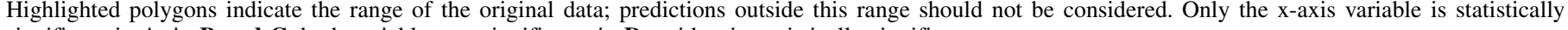
significant in $\mathbf{A}$; in $\mathbf{B}$ and $\mathbf{C}$, both variables are significant; in $\mathbf{D}$, neither is statistically significant. 
primarily observed to impact the lower canopy, meaning that $\mathrm{SNC}$ assessment protocols may be ill-suited for P. pluvialis detection. The possibility of $P$. pluvialis establishing symptomless associations with Douglas fir, prior to any report of early defoliation, remains to be explored. Numerous plant pathogens can have a broad range of ecological interactions with their hosts, including the capacity for asymptomatic colonization before they become pathogenic (Hansen 2008; Malcolm et al. 2013; Porras-Alfaro and Bayman 2011; Stergiopoulos and Gordon 2014).

A longer period of sympatry between $P$. pluvialis and $N$. gaeumannii could have led to spatial niche specialization (Abdullah et al. 2017) at the site level in the Pacific Northwest with variable amounts of both pathogens, which is in contrast to homogeneous levels of $N$. gaeumannii in New Zealand. Our statistical analyses of the regional data indicated that one pathogen typically dominated within each site in the Pacific Northwest (Fig. $6 \mathrm{~A}$ and $\mathrm{C}$; compare individual sites in Fig. 5A and C). This suggested some degree of within-site segregation between both pathogens, but not mutual exclusion, because $N$. gaeumannii was present across all sites. Microscopy revealed the ability of both pathogens to co-infect and sporulate from the stomata of the same needle (Fig. 4). Direct competition and survival of both pathogens within needles warrant further investigation.

Our sampling procedure prioritized detection of $P$. pluvialis by sampling lower branches within a maximum height of $2 \mathrm{~m}$ from the ground. We observed that branches closer to the ground generally cast more needles, and those were frequently P. pluvialis-positive. This observation was in agreement with RNC disease development beginning in the lower crown. A previous study of the vertical distribution of $N$. gaeumannii within the canopy of SNC-infected trees in the Oregon Coast Range found that foliage retention was lowest in the upper canopy (Shaw et al. 2014). This pattern was in contrast to the paradigm generally applied to foliar diseases, which typically favor lower canopy infection (Shaw et al. 2014). This raises the question of whether $P$. pluvialis contributes to this unusual pattern and hints at spatial niche differentiation within a tree (Abdullah et al. 2017). Differential distribution of pathogens within the tree has been suggested in the interaction between Phytophthora ramorum, the causal agent of sudden oak death, and Phytophthora nemorosa, a close relative of P. pluvialis (Kozanitas et al. 2017). The within-tree distribution of $N$. gaeumannii in New Zealand has received little attention. However, in one study based in New Zealand (Hood and Sandberg 1979), lower levels of N. gaeumannii were found in the upper canopy, suggesting a different vertical distribution of spread patterns than in the Pacific Northwest. Understanding within-canopy infection dynamics may further elucidate the role and interaction between both pathogens in needle cast episodes of Douglas fir.

When only the data obtained from sampling every 2 weeks were considered, $N$. gaeumannii had an overall positive impact on P. pluvialis abundance (Table 2, Fig. 3). This positive correlation may be an artifact driven by the large amount of both pathogens present in the New Zealand samples and the low levels of $P$. pluvialis in the Pacific Northwest. The great abundance of $N$. gaeumannii may be explained by the sampling procedure, which forced the detachment of needles from the branches. Prematurely shed needles most likely hold higher pathogen loads than needles remaining on the tree because the abscission of the more heavily infected needles has been recognized as a compensatory mechanism to maintain a positive carbon budget in the tree (Manter et al. 2003). Furthermore, $P$. pluvialis infection may have enhanced $N$. gaeumannii growth rates. Co-infection is thought to trigger higher within-host growth rates as pathogens compete for limited resources (Alizon and van Baalen 2008; Laine 2011). The recent recognition of RNC and patterns of spread throughout New Zealand (Dick et al. 2014; Graham et al. 2018) suggest that P. pluvialis in New Zealand is in its initial phase of colonization. Presumably, establishment will largely rely on niche specialization shaped by environmental conditions conducive to $P$. pluvialis infection and its interactions with symbionts, hosts, antagonists, and competitors (Dickie et al. 2017). In the context of New Zealand, this interaction is likely to be influenced by the association between P. pluvialis and radiata pine. Both interactions may foster further colonization of New Zealand Douglas fir by $P$. pluvialis because these two hosts represent the most widely planted species in New Zealand forestry.

In the Pacific Northwest, our data obtained from sampling every 2 weeks corroborated previous studies that associated SNC severity with mild winter temperatures and wet spring weather in the Pacific Northwest (Lee et al. 2016, 2013; Manter et al. 2005; Rosso and Hansen 2003; Stone et al. 2008b; Zhao et al. 2011), as expected, because the six sampling sites were located within the same area of the cited studies. In our study, $N$. gaeumannii abundance increased with increasing spring $\mathrm{RH}$ values, reaching a peak at $\approx 72 \% \mathrm{RH}$, followed by a decline at higher $\mathrm{RH}$. This effect was notable when winter temperature values exceeded $6^{\circ} \mathrm{C}$. A similar effect was found in New Zealand by Watt et al. (2010), who reported a decline in the $N$. gaeumannii infection index with high spring rainfall. However, this effect was reversed in the regional sampling (i.e., including the Northern California coast), thus supporting previous studies that suggested complex site-specific factors modulating the SNC impact (Lee et al. 2013). Other site characteristics (elevation, aspect) will likely contribute to variability in the $N$. gaeumannii and P. pluvialis abundance in Douglas fir.

Our study confirmed that $P$. pluvialis is a foliar pathogen of Douglas fir in the Pacific Northwest and New Zealand. Both $P$. pluvialis and $N$. gaeumannii appear to be fine-tuned to different ecological conditions through spatial niche specialization in the Pacific Northwest, although both pathogens present great abundance, suggesting competition over limited resources through high growth rates in New Zealand. Mild temperatures in the winter and high RH in the spring, together with the presence of an alternative host, seem to contribute to higher $P$. pluvialis abundance in New Zealand. Further research regarding $P$. pluvialis epidemiology, climate drivers, origin, and ecological role should be conducted to fully elucidate the impacts of $P$. pluvialis and $N$. gaeumannii on Douglas fir. Our findings open a new chapter regarding the research of aerial Phytophthora pathogens and their interaction with foliar fungal diseases in forest systems.

\section{ACKNOWLEDGMENTS}

We thank the Swiss Needle Cast Cooperative, forest growers who provided us with samples and/or access to field sites, and the following who made key contributions: R. Gommers, G. Ritóková, W. Sutton, P. Reeser, and I. Hood. We also thank R. O'Neill, P. Bennett, V. Fieland, S. Kerio, and B. Alvershere for their assistance in the field and with laboratory work.

\section{LITERATURE CITED}

Abdullah, A. S., Moffat, C. S., Lopez-Ruiz, F. J., Gibberd, M. R., Hamblin, J., and Zerihun, A. 2017. Host-multi-pathogen warfare: Pathogen interactions in co-infected plants. Front. Plant Sci. 8:1806.

Al-Naimi, F. A., Garrett, K. A., and Bockus, W. W. 2005. Competition, facilitation, and niche differentiation in two foliar pathogens. Oecologia 143: 449-457.

Alizon, S., Hurford, A., Mideo, N., and Van Baalen, M. 2009. Virulence evolution and the trade-off hypothesis: History, current state of affairs and the future. J. Evol. Biol. 22:245-259.

Alizon, S., and van Baalen, M. 2008. Multiple infections, immune dynamics, and the evolution of virulence. Am. Nat. 172:150-168.

Belda, M., Holtanová, E., Halenka, T., and Kalvová, J. 2014. Climate classification revisited: From Köppen to Trewartha. Clim. Res. 59:1-13.

Boyce, J. S. 1940. A needle cast of Douglas-fir associated with Adelopus gaeumannii. Phytopathology 30:649-659.

Brar, S., Tabima, J. F., McDougal, R. L., Dupont, P. Y., Feau, N., Hamelin, R. C., Panda, P., LeBoldus, J. M., Grünwald, N. J., Hansen, E. M., Bradshaw, R. E., and Williams, N. M. 2018. Genetic diversity of Phytophthora pluvialis, a pathogen of conifers, in New Zealand and the west coast of the United States of America. Plant Pathol. 67:1131-1139. 
Brasier, C., and Webber, J. 2010. Sudden larch death. Nature 466:824-825.

Brasier, C. M., Beales, P. A., Kirk, S. A., Denman, S., and Rose, J. 2005. Phytophthora kernoviae sp. nov., an invasive pathogen causing bleeding stem lesions on forest trees and foliar necrosis of ornamentals in the UK. Mycol. Res. 109:853-859.

Brasier, C. M., Robredo, F., and Ferraz, J. F. P. 1993. Evidence for Phytophthora cinnamomi involvement in Iberian oak decline. Plant Pathol. 42: 140-145.

Bustin, S. A., Benes, V., Garson, J. A., Hellemans, J., Huggett, J., Kubista, M., Mueller, R., Nolan, T., Pfaffl, M. W., Shipley, G. L., Vandesompele, J., and Wittwer, C. T. 2009. The MIQE guidelines: Minimum information for publication of quantitative real-time PCR experiments. Clin. Chem. 55: 611-622.

Day, W. R. 1938. Root-rot of Sweet chestnut and beech caused by species of Phytophthora: I. Cause and symptoms of disease: its relation to soil conditions. Forestry 12:101-116.

Desprez-Loustau, M. L., Massot, M., Toïgo, M., Fort, T., Aday Kaya, A. G., Boberg, J., Braun, U., Capdevielle, X., Cech, T., Chandelier, A., Christova, P., Corcobado, T., Dogmus, T., Dutech, C., Fabreguettes, O., d'Arcier, J. F., Gross, A., Jung, M. H., Iturritxa, E., Jung, T., Junker, C., Kiss, L., Kostov, K., Lehtijarvi, A., Lyubenova, A., Marçais, B., Oliva, J., Oskay, F., Pastirčák, M., Pastirčáková, K., Piou, D., Saint-Jean, G., Sallafranque, A., Slavov, S., Stenlid, J., Talgø, V., Takamatsu, S., and Tack, A. JM. 2018. From leaf to continent: The multi-scale distribution of an invasive cryptic pathogen complex on oak. Fungal Ecol. 36:39-50.

Dick, M. A., Williams, N. M., Bader, M. K.-F., Gardner, J. F., and Bulman, L. S. 2014. Pathogenicity of Phytophthora pluvialis to Pinus radiata and its relation with red needle cast disease in New Zealand. N. Z. J. For. Sci. 44:6.

Dickie, I. A., Bufford, J. L., Cobb, R. C., Desprez-Loustau, M. L., Grelet, G., Hulme, P. E., Klironomos, J., Makiola, A., Nuñez, M. A., Pringle, A., Thrall, P. H., Tourtellot, S. G., Waller, L., and Williams, N. M. 2017. The emerging science of linked plant-fungal invasions. New Phytol. 215: 1314-1332.

Durán, A., Gryzenhout, M., Slippers, B., Ahumada, R., Rotella, A., Flores, F., Wingfield, B. D., and Wingfield, M. J. 2008. Phytophthora pinifolia sp. nov. associated with a serious needle disease of Pinus radiata in Chile. Plant Pathol. 57:715-727.

Erwin, D. C., and Ribeiro, O. K. 1996. Phytophthora Diseases Worldwide. American Phytopathological Society. St. Paul, MN.

Fawke, S., Doumane, M., and Schornack, S. 2015. Oomycete interactions with plants: Infection strategies and resistance principles. Microbiol. Mol. Biol. Rev. 79:263-280.

Fitt, B. D. L., Huang, Y.-J., van den Bosch, F., and West, J. S. 2006. Coexistence of related pathogen species on arable crops in space and time. Annu. Rev. Phytopathol. 44:163-182.

Ganley, R. J., Williams, N. M., Rolando, C. A., Hood, I. A., Dungey, H. S., Beets, P. N., and Bulman, L. S. 2014. Management of red needle cast, caused by Phytophthora pluvialis, a new disease of radiata pine in New Zealand. N. Z. Plant Prot. 67:48-53.

Gómez-Gallego, M., Bader, M. K.-F., Scott, P. M., Leuzinger, S., and Williams, N. M. 2017. Phytophthora pluvialis studies on Douglas-fir require Swiss needle cast suppression. Plant Dis. 101:1259-1262.

Graham, N. J., Suontama, M., Pleasants, T., Li, Y., Bader, M. K. F., Klápště, J., Dungey, H. S., and Williams, N. M. 2018. Assessing the genetic variation of tolerance to red needle cast in a Pinus radiata breeding population. Tree Genet. Genomes 14:55.

Hamilton, N. 2015. smoother: Functions Relating to the Smoothing of Numerical Data. R package version 1.1. https://CRAN.R-project.org/package=smoother

Hansen, E., Reeser, P., Sutton, W., Gardner, J., and Williams, N. 2015. First report of Phytophthora pluvialis causing needle loss and shoot dieback on Douglas-fir in Oregon USA and New Zealand. Plant Dis. 99:727.

Hansen, E. M. 2008. Alien forest pathogens: Phytophthora species are changing world forests. Boreal Environ. Res. 13:33-41.

Hansen, E. M. 2015. Phytophthora species emerging as pathogens of forest trees. Curr. For. Rep. 1:16-24.

Hansen, E. M., Reeser, P. W., Davidson, J. M., Garbelotto, M., Ivors, K., Douhan, L., and Rizzo, D. M. 2003. Phytophthora nemorosa, a new species causing cankers and leaf blight of forest trees in California and Oregon, USA. Mycotaxon 88:129-138.

Hansen, E. M., Reeser, P. W., and Sutton, W. 2017. Ecology and pathology of Phytophthora ITS clade 3 species in forests in western Oregon, USA. Mycologia 109:100-114.

Hansen, E. M., Stone, J. K., Capitano, B. R., Rosso, P., Sutton, W., Winton, L., Kanaskie, A., and McWilliams, M. G. 2000. Incidence and impact of Swiss needle cast in forest plantations of Douglas-fir in coastal Oregon. Plant Dis. 84:773-778

Hayden, K. J., Hardy, G. E. S. J., and Garbelotto, M. 2013. Oomycete diseases. Pages 519-546 in: Infectious Forest Diseases. P. Gonthier and G. Nicolotti, eds. CABI, Wallingford, U.K
Hood, I. A., and Kershaw, D. J. 1975. Distribution and infection period of Phaeocryptopus gaeumannii in New Zealand. N. Z. J. For. Sci. 5:201-208.

Hood, I. A., and Sandberg, C. J. 1979. Changes within tree crowns following thinning of young Douglas-fir infected by Phaeocryptopus gaeumannii. N. Z. J. For. Sci. 9:177-184

Hood, I. A., Sandberg, C. J., Barr, C. W., Holloway, W. A., and Bradbury, P. M. 1990. Changes in needle retention associated with the spread and establishment of Phaeocryptopus gaeumannii in planted Douglas fir. Eur. J. Forest Pathol. 20:418-429.

Jonkers, W., Estrada, A. E. R., Lee, K., Breakspear, A., May, G., and Kistler, H. C. 2012. Metabolome and transcriptome of the interaction between Ustilago maydis and Fusarium verticillioides in vitro. Appl. Environ. Microbiol. 78:3656-3667.

Kozanitas, M., Osmundson, T. W., Linzer, R., and Garbelotto, M. 2017. Interspecific interactions between the Sudden Oak Death pathogen Phytophthora ramorum and two sympatric Phytophthora species in varying ecological conditions. Fungal Ecol. 28:86-96.

Laine, A. L. 2011. Context-dependent effects of induced resistance under coinfection in a plant-pathogen interaction. Evol. Appl. 4:696-707.

Lee, E. H., Beedlow, P. A., Waschmann, R. S., Burdick, C. A., and Shaw, D. C. 2013. Tree-ring analysis of the fungal disease Swiss needle cast in western Oregon coastal forests. Can. J. For. Res. 43:677-690.

Lee, E. H., Beedlow, P. A., Waschmann, R. S., Tingey, D. T., Wickham, C., Cline, S., Bollman, M., and Carlile, C. 2016. Douglas-fir displays a range of growth responses to temperature, water, and Swiss needle cast in western Oregon, USA. Agric. For. Meteorol. 221:176-188.

Luedeling, E. 2019. chillR: Statistical Methods for Phenology Analysis in Temperate Fruit Trees. R package version 0.70.17. https:/CRAN.R-project.org/ package $=$ chillR

Malcolm, G. M., Kuldau, G. A., Gugino, B. K., and Jiménez-Gasco, M. del M. 2013. Hidden host plant associations of soilborne fungal pathogens: An ecological perspective. Phytopathology 103:538-544.

Manter, D. K., Bond, B. J., Kavanagh, K. L., Rosso, P. H., and Filip, G. M. 2000. Pseudothecia of Swiss needle cast fungus, Phaeocryptopus gaeumannii, physically block stomata of Douglas fir, reducing $\mathrm{CO}_{2}$ assimilation. New Phytol. 148:481-491.

Manter, D. K., Bond, B. J., Kavanagh, K. L., Stone, J. K., and Filip, G. M. 2003. Modelling the impacts of the foliar pathogen, Phaeocryptopus gaeumannii, on Douglas-fir physiology: net canopy carbon assimilation, needle abscission and growth. Ecol. Modell. 164:211-226.

Manter, D. K., Reeser, P. W., and Stone, J. K. 2005. A climate-based model for predicting geographic variation in Swiss needle cast severity in the Oregon Coast Range. Phytopathology 95:1256-1265.

Mideo, N. 2009. Parasite adaptations to within-host competition. Trends Parasitol. 25:261-268.

Newhook, F., and Podger, F. 1972. The role of Phytophthora cinnamomi in Australian and New Zealand forests. Annu. Rev. Phytopathol. 10: 299-326

Nowak, M. A., and May, R. M. 1994. Superinfection and the evolution of parasite virulence. Proc. R. Soc. Biol. Sci. 255:81-89.

Porras-Alfaro, A., and Bayman, P. 2011. Hidden fungi, emergent properties: Endophytes and microbiomes. Annu. Rev. Phytopathol. 49:291-315.

R Core Team. 2017. R: A Language and Environment for Statistical Computing. https://www.R-project.org/

Rankin, D. J., Bargum, K., and Kokko, H. 2007. The tragedy of the commons in evolutionary biology. Trends Ecol. Evol. 22:643-651.

Reeser, P., Sutton, W., and Hansen, E. 2013. Phytophthora pluvialis, a new species from mixed tanoak-Douglas-fir forests of western Oregon, U.S.A. N. Am. Fungi 8:1-8.

Ritóková, G., Shaw, D. C., Filip, G., Kanaskie, A., Browning, J., and Norlander, D. 2016. Swiss needle cast in western Oregon Douglas-fir plantations: 20-Year monitoring results. Forests 7:155.

Rosso, P. H., and Hansen, E. M. 2003. Predicting swiss needle cast disease distribution and severity in young Douglas-fir plantations in coastal Oregon. Phytopathology 93:790-798.

Shaw, D., Woolley, T., and Kanaskie, A. 2014. Vertical foliage retention in Douglas-fir across environmental gradients of the Western Oregon Coast range influenced by Swiss needle cast. Northwest Sci. 88:23-32.

Simpson, D. R., Thomsett, M. A., and Nicholson, P. 2004. Competitive interactions between Microdochium nivale var. majus, $M$. nivale var. nivale and Fusarium culmorum in planta and in vitro. Environ. Microbiol. 6:79-87

Stergiopoulos, I., and Gordon, T. R. 2014. Cryptic fungal infections: the hidden agenda of plant pathogens. Front. Plant Sci. 5:10-13.

Stone, J. K., Capitano, B. R., and Kerrigan, J. L. 2008a. The histopathology of Phaeocryptopus gaeumannii on Douglas-fir needles. Mycologia 100:431-444.

Stone, J. K., Coop, L. B., and Manter, D. K. 2008b. Predicting effects of climate change on Swiss needle cast disease severity in Pacific Northwest forest. Can. J. Plant Pathol. 30:169-176. 
Stone, J. K., Hood, I. A., Watt, M. S., and Kerrigan, J. L. 2007. Distribution of Swiss needle cast in New Zealand in relation to winter temperature. Australas. Plant Pathol. 36:445-454.

Telfer, E., Graham, N., Stanbra, L., Manley, T., and Wilcox, P. 2013. Extraction of high purity genomic DNA from pine for use in a high-throughput genotyping platform. N. Z. J. For. Sci. 43:3.

van Baalen, M., and Sabelis, M. W. 1995. The dynamics of multiple infection and the evolution of virulence. Am. Nat. 146:881-910.

Vettraino, A. M., Morel, O., Perlerou, C., Robin, C., Diamandis, S., and Vannini, A. 2005. Occurrence and distribution of Phytophthora species in European chestnut stands, and their association with ink disease and crown decline. Eur. J. Plant Pathol. 111:169-180.

Watt, M. S., Stone, J. K., Hood, I. A., and Palmer, D. J. 2010. Predicting the severity of Swiss needle cast on Douglas-fir under current and future climate in New Zealand. For. Ecol. Manage. 260:2232-2240.
Winton, L. M., Manter, D. K., Stone, J. K., and Hansen, E. M. 2003. Comparison of biochemical, molecular, and visual methods to quantify Phaeocryptopus gaeumannii in Douglas-fir foliage. Phytopathology 93: 121-126.

Winton, L. M., Stone, J. K., Watrud, L. S., and Hansen, E. M. 2002. Simultaneous one-tube quantification of host and pathogen DNA with real-time polymerase chain reaction. Phytopathology 92:112-116.

Wood, S. N. 2011. Fast stable restricted maximum likelihood and marginal likelihood estimation of semiparametric generalized linear models. J. Roy. Stat. Soc. B 73:3-36.

Wood, S. N. 2017. Generalized Additive Models: An Introduction with R. 2nd ed. Chapman and Hall/CRC Press, Boca Raton, FL.

Zhao, J., Mainwaring, D. B., Maguire, D. A., and Kanaskie, A. 2011. Regional and annual trends in Douglas-fir foliage retention: Correlations with climatic variables. For. Ecol. Manage. 262:1872-1886. 